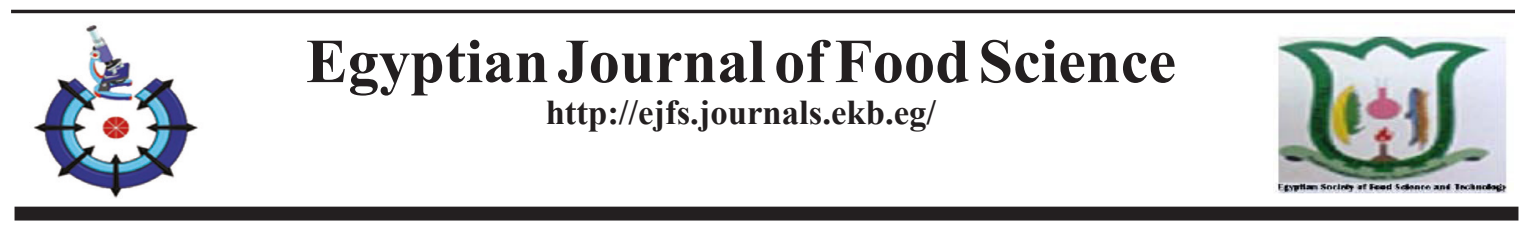

\title{
Novel Probiotic Adjunct Cultures for The Production of Fruit- Flavoured Drinkable Yoghurt
}

\author{
Elsayed A. Ismail ${ }^{1 *}$, Mohamed E. Shenana ${ }^{1}$, Mohamed B. El-Alfy ${ }^{1}$, Ehab A. \\ Essawy $^{2}$, and Sanaa E. Abd El-Halim ${ }^{2}$ \\ ${ }^{1}$ Dairy Sci., Dept., Fac., of Agric., Moshtohor, Benha University, Egypt. \\ ${ }^{2}$ Dairy Res., Dept., Food Tech., Res., Institute, Agric., Res., Center, Ministry of \\ Agriculture, Egypt.
}

\begin{abstract}
JOWADAYS, there is a good demand for fruit drinkable yoghurt containing probiotics. 1 Yoghurt is more nutritious than many other fermented milk products because it contains a high level of milk solids in addition to nutrients developed during the fermentation process. The aim of the present study was to produce fruit-flavoured drinkable yoghurt by using new isolates of Bifidobacterium breve and Lactobacillus plantarum as probiotic strains and in the enrichment with fruit juices (red grape or apricot), Furthermore, evaluation of physico-chemical, rheological, microbiological, sensorial properties and antioxidant activity of fruit-flavoured drinkable yoghurt during storage. The addition of probiotic bacteria such as Lactobacillus and Bifidobacterium sp. to yoghurt improves its functionality and healthy effects. In this study fruit-flavoured drinkable yoghurt containing two ratios of red grape and apricot juices $(7.5 \%$ and $10 \%$ ) and $7.5 \%$ sugar were produced by using novel isolates of Bifidobacterium breve and Lactobacillus plantarum. Chemical, microbiological, and sensorial properties, beside nutritional characteristics of drinkable yoghurt were improved by adding $10 \%$ red grape or apricot juice and $1.5 \%$ probiotic bacteria $B$. breve and $L$. plantarum and enriched with $1 \%$ oat.
\end{abstract}

Keywords: probiotics, fruit-flavoured drinkable yoghurt, Lactobacillus, Bifidobacterium.

\section{Introduction}

Drinkable yoghurt is a traditional fermented dairy beverage, which has growing area of interest due to its ability to deliver all the health benefits, nutritional benefit of regular set yoghurt or stirred yoghurt. Moreover, drinkable yoghurts meet consumer demand for portable, hand-held meals that fit an on-the-go lifestyle. However, drinkable yoghurt goes to the group of stirred yoghurt, which has low viscosity (Allgeyer et al., 2010). Yoghurt drinks should contain (>8.25\%) milk solids-not-fat and fat levels to satisfy nonfat yoghurt $(<0.5 \%)$, low-fat yoghurt $(2 \%)$, or full-fat yoghurt $(>3.25 \%)$ before the addition of other ingredients. The most common types of probiotics are species of Lactobacillus and Bifidobacterium genera. These genera are mostly given the generally recognized as safe (GRAS) status. Supplementation of probiotic yoghurt with prebiotics is important to improve the features of probiotic bacteria during storage. Buriti et al. (2007) and Cardarelli et al. (2007) reported that there are non-digestible food ingredients such as oat that beneficially affect the host by selectively stimulating the growth and/or activity bacteria in the colon. Fortifying yoghurt with fiber is to create functional foods with health benefits and improve their functionality. Oats (Avena sativa) are wholegrain cereals mainly grown in North America and Europe. Oats, have received considerable interest in recent years as a delivery vehicles for probiotics due to their high content of soluble and insoluble fibers such as $\beta$-glucan, arabinoxylans and cellulose, in addition to relatively high levels of protein, lipids (un-saturated fatty acids), vitamins, minerals, antioxidants and phenolic compounds. Due to their valuable functional, industrial and health benefits, such as lowering blood sugar

*Corresponding author : E-mail: e.ismail@fagr.bu.edu.eg, sayed1973@yahoo.com

Received:20/6/2020; accepted:9/8/2020

DOI: $10.21608 /$ EJFS.2020.33315.1061

(C)2020 National Information and Documentation Centre (NIDOC) 
and cholesterol levels (zero cholesterol and zero trans-fatty acids), oats have gained considerable attention as a health food (Tiwari et al., 2019). Recently, probiotic fermented dairy products that provide a healthy functional food is advised for better health. Probiotic yoghurt has been shown to cause an increase in human gut bacterial content. These bacteria ferment food-derived indigestible carbohydrates. Such fermentation causes increased production of short-chain fatty acids, which decreases circulatory cholesterol concentrations either by inhibiting hepatic cholesterol synthesis or by redistributing cholesterol from plasma to the liver (St-Onge et al., 2000). Furthermore, increased bacterial activity in the large intestine results in enhanced bile acid de-conjugation (StOnge et al., 2000).

The objective of the present investigation was to produce fruit-flavoured drinkable yoghurt by using new isolates of Bifidobacterium breve and Lactobacillus plantarum as probiotic strains and in the enrichment with fruit juices (red grape or apricot), Furthermore, evaluation of physicochemical, rheological, microbiological, sensorial properties and antioxidant activity of fruitflavoured drinkable yoghurt during storage was performed.

\section{Materials and Methods}

Fresh mixed cow's and buffalo's milks (1:1) were obtained from the herds of Agriculture Faculty, Benha University, Egypt. Freeze dried conventional yoghurt starter culture (FD-DVS YC-X11-Yo-Flex) containing Lactobacillus delbrueckii ssp. bulgaricus and Streptococcus thermophilus (1:1) was obtained from Chr. Hansen's Laboratories, Copenhagen, Denmark and purchased from MIFAD Company, Egypt. Lactobacillus plantarum ATCC 14917 was obtained from National Research Center, Giza, Egypt. BifidobacteriumbreveIso8 was isolated from infants by (Ismail, 2007). White oat flakes whole grain (DOBELLA), originated by European Union and imported from Elmashreq-gardens Company, Cairo, Egypt and was purchased from local market.

\section{Preparation of the Fruit-Flavoured probiotic drinkable yoghurt}

Fresh mixed cow's and buffalo's milk (1:1) was standardized to $\sim 4.5 \%$ fat and $1 \%$ oat was added, heated to $90^{\circ} \mathrm{C}$ for $10 \mathrm{~min}$., immediately cooled down to $42^{\circ} \mathrm{C}$, then divided into portions, and $1.5 \%$ of probiotic strains were added. All treatments except $\mathrm{C}_{1}$ and $\mathrm{C}_{2}[\mathrm{C} 1$ : Control without oat, $\mathrm{C} 2$ : Control with $1 \%$ oat] were inoculated individually with $1.5 \%$ of probiotic strains ( $B$. breve or $L$. plantarum) and incubated for one hour at $42^{\circ} \mathrm{C}$. The yoghurt was then inoculated with $0.02 \%$ of freeze-dried conventional yoghurt starter culture for all treatments and continuously incubated at $42^{\circ} \mathrm{C}$ to reach the $\mathrm{pH}$ of about $\sim 4.6$, then directly refrigerated at $\sim 5^{\circ} \mathrm{C}$ (Tamime \& Robinson, 1999). In the next day, the yoghurts were mixed with two ratios of apricot and red grape juices $(7.5 \%$ and $10 \%)$ and $7.5 \%$ sugar were added. Then, all treatments, $\left(\mathrm{C}_{1}, \mathrm{C}_{2}, \mathrm{~T}_{1}, \mathrm{~T}_{2}, \mathrm{~T}_{3}, \mathrm{~T}_{4}\right.$, $\mathrm{T}_{5}, \mathrm{~T}_{6}, \mathrm{~T}_{7}$, and $\mathrm{T}_{8}\left[\mathrm{~T}_{1}: 7.5 \%\right.$ red grape juice + $1.5 \%$ B. breve $+1 \%$ oat., $\mathrm{T}_{2}: 10 \%$ red grape juice $+1.5 \%$ B. breve $+1 \%$ oat., $\mathrm{T}_{3}: 7.5 \%$ red grape juice $+1.5 \%$ L. plantarum $+1 \%$ oat., $\mathrm{T}_{4}: 10 \%$ red grape juice $+1.5 \%$ L. plantarum $+1 \%$ oat., $\mathrm{T}_{5}$ : $7.5 \%$ apricot juice $+1.5 \%$ B. breve $+1 \%$ oat., $\mathrm{T}_{6}: 10 \%$ apricot juice $+1.5 \%$ B. breve $+1 \%$ oat., $\mathrm{T}_{7}: 7.5 \%$ apricot juice $+1.5 \%$ L. plantarum $+1 \%$ oat., $\mathrm{T}_{8}: 10 \%$ apricot juice $+1.5 \%$ L. plantarum + $1 \%$ oat.] were strongly whipped and immediately filled into sterilized glass bottles $(200 \mathrm{ml})$ and stored in refrigerator $\left(\sim 5^{\circ} \mathrm{C}\right)$ and analysed for physico-chemical, rheological, microbiological and sensorial properties when fresh and after 7 , 14 and 21 days.

\section{Analysis of Physico-chemical properties}

Total solids, protein, fat, water soluble nitrogen contents were determined according to the methodology mentioned in AOAC (2012). Carbohydrates content was estimated by difference as following: $\%$ carbohydrates $=\%$ total solids- $\%$ (fat + protein + ash). Titratable acidity was determined according to British Standards Institution (BSI, 2010). The $\mathrm{pH}$ values were measured using a digital laboratory $\mathrm{pH}$ meter (model HANNA pH 213 instruments) with combined glass electrode according to the methods of BSI (1985). Total volatile fatty acid (TVFA) content was determined by the direct distillation method as described by Kosikowski (1984). Acetaldehyde and diacetyl contents were determined according to Lees \& Jago (1969) and (1970), respectively.

\section{Rheological analysis}

Water holding capacity was measured by centrifugal method according to a modified method of Keogh \& O'Kennedy (1998). The apparent viscosity (centi poise) was measured using Brookfield Engineering Labs DV III ultrarheometer, Inc. Stoughton, MA, USA, according to Petersen et al. (2000). 


\section{Microbiological examinations}

Total bacterial count (TBC) for the produced yoghurt samples were done according to American Public Health Association (APHA, 2004). Lactic acid bacterial count (LAB) was enumerated according to Elliker et al. (1956). Str. thermophilus was counted on the M17 agar medium supplemented with $0.5 \%$ lactose according to de Souza et al. (2008). Yeast and moulds counts were enumerated as described by APHA, (2004). Coliform bacteria group was tested as suggested by the BSI (1993). Sporeforming bacterial counts were enumerated on plate count agar medium as given by Marshall (2005). Bifidobacterium ssp. was counted by using modified De Man, Rogosa and Sharpe agar (MRS agar) supplemented with $0.05 \%$ L-cysteine and $0.3 \%$ lithium chloride according to Dave \& Shah (1996). L. plantarum count was done according to Bujalance et al. (2006) on L. plantarum selective medium (LPSM). The plates of Bifidobacteria and Lactobacilli strains were anaerobically incubated at $37^{\circ} \mathrm{C}$ for $3-4$ days in anaerobic jars (with $\mathrm{CO}_{2}$ injection).

\section{Sensory evaluation}

Sensory evaluation was done by 10 experienced panelists of staff members of dairy department, faculty of agriculture, Benha University, Egypt. Synbiotic-drinkable yoghurt was judged when fresh, and during storage period according to Tamime \& Robinson (1999).

\section{Statistical analysis}

Statistical analysis was performed according to Statistical Analysis System SAS (2008) using General Linear Model (GLM) with main effect of treatment. Duncan's multiple range was used to separate among of three replicates at $(\mathrm{P} 0.05<)$.

\section{Results and Discussion}

Physico-chemical composition of probiotic fruitflavoured drinkable yoghurt

Table 1 shows the physico-chemical properties of red grape juice, apricot juice, and raw milk used in preparation of fruit-flavoured drinkable yoghurt. Results indicated that the total solids, carbohydrates, and total flavonoids contents were higher in red grape juice than in apricot juice while the ash content of apricot juice was higher than of red grape juice.

The data in Table 2 show the physico-chemia cal properties of probiotic fruit-flavoured drinkable yoghurt when fresh and during storage. The total solids contents of fresh treatments were ranged from 20.64 to $21.99 \%$. During the storage period the total solids were increased gradually in all treatments up to 21 days. The increase of total solids of all treatments might be related to the slightly moisture evaporation during cold storage period. These results agree with Abdel-Galeele et al. (2013), Ismail et al. (2016), Subhashini et al. (2018) and Hammad (2019). It was noticed that fruit juices enrichment caused slightly increase in total solids content which was proportional to the increase of fruit juices added. This could be due to the highest values of total solids which observed with treatments containing high percentages of red grape juice $(10 \%)$, as the red grape contains more solids than apricot. These results are like those of Gunawardhana \& Dilrukshi (2016), Ahmed (2017) and Subhashini et al. (2018).

TABLE 1. Physico-chemical analysis of red grape juice, apricot juice, and raw mixed milk used in preparation of fruit-flavoured drinkable yoghurt.

\begin{tabular}{lccc}
\hline Parameter & Red grape juice & Apricot juice & $\begin{array}{c}\text { Raw mixed milk } \\
(\mathbf{1 : 1 )}\end{array}$ \\
\hline T.S (\%) & 18.98 & 14.64 & 13.56 \\
Ash (\%) & 0.59 & 3.10 & 0.74 \\
pH values & 5.01 & 4.46 & 6.73 \\
Acidity (\%) & 0.47 & 2.10 & 0.16 \\
Fat (\%) & 0.89 & 0.63 & 4.55 \\
Protein (\%) & 0.63 & 1.43 & 3.31 \\
Carbohydrates (\%) & 16.87 & 9.48 & n.d \\
Crude fibers (\%) & 0.49 & 1.98 & n.d \\
Antioxidant activity \% (DPPH) & 47.96 & 45.33 & n.d \\
Total phenolic content & 89.01 & 84.37 & n.d \\
(mg GAE/100g) & 61.22 & 42.69 & 1.034 \\
Total flavonoids content (mg QE/100g) & n.d & n.d & \\
Specific gravity & & & \\
\hline
\end{tabular}

n.d: Not determined 
TABLE 2. Physio-chemical properties of fruit-flavourd drinkable yoghurt when fresh and during storage at $\sim 5^{\circ} \mathrm{C}$ up to 21 days.

\begin{tabular}{|c|c|c|c|c|c|c|c|c|c|c|}
\hline \multirow{2}{*}{$\begin{array}{c}\text { Storage } \\
\text { (days) }\end{array}$} & $\mathrm{C}_{1}$ & $\mathrm{C}_{2}$ & $T_{1}$ & $\mathbf{T}_{2}$ & $\mathbf{T}_{3}$ & $\mathbf{T}_{4}$ & $\mathbf{T}_{5}$ & $T_{6}$ & $\mathbf{T}_{7}$ & $T_{8}$ \\
\hline & \multicolumn{10}{|c|}{ T.S (\%) } \\
\hline Fresh & $20.64^{\mathrm{Aa}}$ & $21.14^{\mathrm{Aa}}$ & $21.49^{\mathrm{Aa}}$ & $21.96^{\mathrm{Aa}}$ & $21.68^{\mathrm{Aa}}$ & $21.99^{\mathrm{Aa}}$ & $21.16^{\mathrm{Aa}}$ & $21.39^{\mathrm{Aa}}$ & $21.19^{\mathrm{Aa}}$ & $21.37^{\mathrm{Aa}}$ \\
\hline 7 & $20.66^{\mathrm{Aa}}$ & $21.22^{\mathrm{Aa}}$ & $21.55^{\mathrm{Aa}}$ & $22.04^{\mathrm{Aa}}$ & $21.80^{\mathrm{Aa}}$ & $22.05^{\mathrm{Aa}}$ & $21.24^{\mathrm{Aa}}$ & $21.46^{\mathrm{Aa}}$ & $21.32^{\mathrm{Aa}}$ & $21.41^{\mathrm{Aa}}$ \\
\hline 14 & $20.77^{\mathrm{Aa}}$ & $21.25^{\mathrm{Aa}}$ & $21.65^{\mathrm{Aa}}$ & $22.11^{\mathrm{Aa}}$ & $21.87^{\mathrm{Aa}}$ & $22.10^{\mathrm{Aa}}$ & $21.34^{\mathrm{Aa}}$ & $21.51^{\mathrm{Aa}}$ & $21.35^{\mathrm{Aa}}$ & $21.48^{\mathrm{Aa}}$ \\
\hline 21 & $20.84^{\mathrm{Aa}}$ & $21.39^{\text {Аa }}$ & 21.72 Аа & $22.16^{\mathrm{Aa}}$ & $21.95^{\mathrm{Aa}}$ & $22.14^{\mathrm{Aa}}$ & $21.43^{\mathrm{Aa}}$ & $21.56^{\mathrm{Aa}}$ & $21.46^{\mathrm{ABa}}$ & $21.53^{\mathrm{Aa}}$ \\
\hline \multicolumn{11}{|c|}{ Protein (\%) } \\
\hline Fresh & $3.25^{\mathrm{BCd}}$ & $3.37^{\mathrm{Ad}}$ & $3.19^{\mathrm{CDEd}}$ & $3.15^{\mathrm{Ed}}$ & $3.21^{\mathrm{BCDd}}$ & $3.16^{\mathrm{DEd}}$ & $3.27^{\mathrm{Bd}}$ & $3.19^{\mathrm{CDEd}}$ & $3.26^{\mathrm{Bd}}$ & $3.23^{\mathrm{BCd}}$ \\
\hline 7 & $3.31^{\mathrm{Bc}}$ & $3.45^{\mathrm{Ac}}$ & $3.26^{\mathrm{CDc}}$ & $3.21^{\mathrm{Dc}}$ & $3.30^{\mathrm{CDc}}$ & $3.24^{\mathrm{Dc}}$ & $3.34^{\mathrm{Bc}}$ & $3.28^{\mathrm{Dc}}$ & $3.35^{\mathrm{Bc}}$ & $3.33^{\mathrm{Bc}}$ \\
\hline 14 & $3.35^{\mathrm{DEb}}$ & $3.48^{\mathrm{Ab}}$ & $3.33^{\mathrm{DEb}}$ & $3.26^{\mathrm{Fb}}$ & $3.34^{\mathrm{CDEb}}$ & $3.30^{\mathrm{Eb}}$ & $3.42^{\mathrm{Bb}}$ & $3.35^{\mathrm{CDEb}}$ & $3.41^{\mathrm{BCb}}$ & $3.38^{\mathrm{BCDb}}$ \\
\hline 21 & $3.44^{\mathrm{DEa}}$ & $3.55^{\mathrm{Aa}}$ & $3.40^{\mathrm{Da}}$ & $3.35^{\mathrm{Ea}}$ & $3.43^{\mathrm{CDa}}$ & $3.36^{\mathrm{Ea}}$ & $3.51^{\mathrm{ABa}}$ & $3.42^{\mathrm{CDa}}$ & $3.49^{\mathrm{ABCa}}$ & $3.45^{\mathrm{BCDa}}$ \\
\hline \multicolumn{11}{|c|}{ Fat $(\%)$} \\
\hline Fresh & $4.55^{\mathrm{Ad}}$ & $4.58^{\mathrm{Ad}}$ & $4.22^{\mathrm{Bd}}$ & $4.13^{\mathrm{Cd}}$ & $4.24^{\mathrm{Bd}}$ & $4.11^{\mathrm{Cd}}$ & $4.25^{\mathrm{Bd}}$ & $4.14^{\mathrm{Cd}}$ & $4.27^{\mathrm{Bd}}$ & $4.15^{\mathrm{Cd}}$ \\
\hline 7 & $4.63^{\mathrm{Bc}}$ & $4.69^{\mathrm{Ac}}$ & $4.38^{\mathrm{Cc}}$ & $4.25^{\mathrm{Dc}}$ & $4.36^{\mathrm{Cc}}$ & $4.22^{\mathrm{Dc}}$ & $4.37^{\mathrm{Cc}}$ & $4.28^{\mathrm{Dc}}$ & $4.39^{\mathrm{Cc}}$ & $4.26^{\mathrm{Dc}}$ \\
\hline 14 & $4.75^{\mathrm{Ab}}$ & $4.78^{\mathrm{Ab}}$ & $4.45^{\mathrm{BCb}}$ & $4.37^{\mathrm{CDb}}$ & $4.48^{\mathrm{CDb}}$ & $4.30^{\mathrm{Db}}$ & $4.51^{\mathrm{Bb}}$ & $4.39^{\mathrm{CDb}}$ & $4.52^{\mathrm{Bb}}$ & $4.37^{\mathrm{CDb}}$ \\
\hline 21 & $4.85^{\mathrm{Aa}}$ & $4.92^{\mathrm{Aa}}$ & $4.52^{\mathrm{Da}}$ & $4.45^{\mathrm{Da}}$ & $4.57^{\mathrm{CDa}}$ & $4.38^{\mathrm{Ea}}$ & $4.60^{\mathrm{Ca}}$ & $4.47^{\mathrm{Da}}$ & $4.61^{\mathrm{Ca}}$ & $4.50^{\mathrm{Da}}$ \\
\hline \multicolumn{11}{|c|}{$\operatorname{Ash}(\%)$} \\
\hline Fresh & $0.70^{\mathrm{Cb}}$ & $0.74^{\mathrm{Cb}}$ & $0.72^{\mathrm{Cb}}$ & $0.72^{\mathrm{Cb}}$ & $0.73^{\mathrm{Cb}}$ & $0.72^{\mathrm{Cb}}$ & $0.89^{\mathrm{Bb}}$ & $0.97^{\mathrm{Ab}}$ & $0.90^{\mathrm{ABb}}$ & $0.99^{\mathrm{Ab}}$ \\
\hline 7 & $0.71^{\mathrm{Cb}}$ & $0.75^{\mathrm{CDb}}$ & $0.73^{\mathrm{Cb}}$ & $0.73^{\mathrm{Cb}}$ & $0.74^{\mathrm{Cb}}$ & $0.73^{\mathrm{Cb}}$ & $0.90^{\mathrm{Bb}}$ & $0.98^{\mathrm{ABb}}$ & $0.91^{\mathrm{ABb}}$ & $1.00^{\mathrm{Ab}}$ \\
\hline 14 & $0.72^{\text {Aab }}$ & $0.76^{\mathrm{CDab}}$ & $0.75^{\text {CDEab }}$ & $0.74^{\text {DEab }}$ & $0.76^{\mathrm{CDab}}$ & $0.75^{\text {DEab }}$ & $0.91^{\mathrm{Bab}}$ & $0.99^{\text {Aab }}$ & $0.92^{\mathrm{Bab}}$ & $1.01^{\mathrm{Aab}}$ \\
\hline 21 & $0.73^{\mathrm{Ea}}$ & $0.78^{\mathrm{CDa}}$ & $0.76^{\mathrm{CDEa}}$ & $0.75^{\text {DEa }}$ & $0.77^{\mathrm{CDa}}$ & $0.76^{\text {DEa }}$ & $0.93^{\mathrm{Ba}}$ & $1.01^{\mathrm{Aa}}$ & $0.93^{\mathrm{Ba}}$ & $1.02^{\mathrm{Aa}}$ \\
\hline \multicolumn{11}{|c|}{ Carbohydrate (CHO \%) } \\
\hline Fresh & $12.14^{\mathrm{Ac}}$ & $12.45^{\mathrm{A}} \mathrm{c}$ & $13.36^{\mathrm{Ac}}$ & $13.96^{\mathrm{Ac}}$ & $13.50^{\mathrm{Ac}}$ & $14.00^{\mathrm{Ac}}$ & $12.75^{\mathrm{Ac}}$ & $13.09^{\mathrm{Ac}}$ & $12.76^{\mathrm{Ac}}$ & $13.00^{\mathrm{Ac}}$ \\
\hline 7 & $12.01^{\mathrm{Abc}}$ & $12.33^{\mathrm{Abc}}$ & $13.18^{\mathrm{Abc}}$ & $13.85^{\mathrm{Ac}}$ & $13.40^{\mathrm{Abc}}$ & $13.86^{\mathrm{Abc}}$ & $12.63^{\mathrm{Abc}}$ & $12.92^{\mathrm{Abc}}$ & $12.67^{\mathrm{Abc}}$ & $12.82^{\mathrm{Abc}}$ \\
\hline 14 & $11.95^{\mathrm{Aab}}$ & $12.2^{3 \mathrm{Aab}}$ & $13.12^{\mathrm{Aab}}$ & $13.74^{\mathrm{Aa}}$ & $13.29^{\mathrm{Aab}}$ & $13.75^{\mathrm{Aab}}$ & $12.49^{\mathrm{Aab}}$ & $12.78^{\mathrm{Aab}}$ & $12.50^{\mathrm{Aab}}$ & $12.72^{\mathrm{Aab}}$ \\
\hline 21 & $11.84^{\mathrm{Aa}}$ & $12.14^{\mathrm{Aa}}$ & $13.03^{\mathrm{Aa}}$ & $13.60^{\mathrm{Aa}}$ & $13.17^{\mathrm{Aa}}$ & $13.63^{\mathrm{Aa}}$ & $12.39^{\mathrm{Aa}}$ & $12.66^{\mathrm{Aa}}$ & $12.43^{\mathrm{Aa}}$ & $12.56^{\mathrm{Aa}}$ \\
\hline \multicolumn{11}{|c|}{ Titratable acidity (\%) } \\
\hline Fresh & $0.65^{\mathrm{Ad}}$ & $0.68^{\mathrm{Ad}}$ & $0.71^{\mathrm{Ad}}$ & $0.72^{\mathrm{Ad}}$ & $0.70^{\mathrm{Ad}}$ & $0.72^{\mathrm{Ad}}$ & $0.74^{\mathrm{Ad}}$ & $0.76^{\mathrm{Ad}}$ & $0.73^{\mathrm{Ad}}$ & $0.78^{\mathrm{Ad}}$ \\
\hline 7 & $0.74^{\mathrm{Cc}}$ & $0.79^{\mathrm{Cc}}$ & $0.85^{\mathrm{BCc}}$ & $0.86 \mathrm{~B}^{\mathrm{Cc}}$ & $0.84^{\mathrm{BCc}}$ & $0.87^{\mathrm{ABc}}$ & $0.89^{\mathrm{ABc}}$ & $0.94^{\mathrm{Ac}}$ & $0.91^{\mathrm{Ac}}$ & $0.95^{\mathrm{Ac}}$ \\
\hline 14 & $0.83^{\mathrm{Fb}}$ & $0.86^{\mathrm{EFb}}$ & $0.91^{\mathrm{DEb}}$ & $0.95^{\mathrm{CDb}}$ & $0.92^{\mathrm{DEb}}$ & $0.96^{\mathrm{CDb}}$ & $0.97^{\mathrm{BCDb}}$ & $1.05^{\mathrm{Ab}}$ & $0.99^{\mathrm{ABCb}}$ & $1.02^{\mathrm{ABb}}$ \\
\hline 21 & $0.88^{\mathrm{Fa}}$ & $0.91^{\mathrm{EFa}}$ & $0.99^{\mathrm{CDEa}}$ & $1.01^{\mathrm{CDa}}$ & $0.98^{\mathrm{DEa}}$ & $1.02^{\mathrm{CDa}}$ & $1.06^{\mathrm{BCa}}$ & $1.11^{\mathrm{ABa}}$ & $1.05^{\mathrm{BCDa}}$ & $1.14^{\mathrm{Aa}}$ \\
\hline \multicolumn{11}{|c|}{ pH values } \\
\hline Fresh & $4.68^{\mathrm{Aa}}$ & $4.64^{\mathrm{Aa}}$ & $4.63^{\mathrm{Aa}}$ & $4.61^{\mathrm{Aa}}$ & $4.64^{\mathrm{Aa}}$ & $4.60^{\mathrm{Aa}}$ & $4.59^{\mathrm{Aa}}$ & $4.53^{\mathrm{Aa}}$ & $4.56^{\mathrm{Aa}}$ & $4.52^{\mathrm{Aa}}$ \\
\hline 7 & $4.43^{\mathrm{Ab}}$ & $4.40^{\mathrm{Ab}}$ & $4.31^{\mathrm{Ab}}$ & $4.27^{\mathrm{Ab}}$ & $4.33^{\mathrm{Ab}}$ & $4.28^{\mathrm{Ab}}$ & $4.27^{\mathrm{Ab}}$ & $4.25^{\mathrm{Ab}}$ & $4.28^{\mathrm{Ab}}$ & $4.21^{\mathrm{Ab}}$ \\
\hline 14 & $4.31^{\mathrm{Ac}}$ & $4.27^{\mathrm{Ac}}$ & $4.19^{\mathrm{Ac}}$ & $4.17^{\mathrm{Ac}}$ & $4.20^{\mathrm{Ac}}$ & $4.15^{\mathrm{Ac}}$ & $4.11^{\mathrm{Ac}}$ & $4.09^{\mathrm{Ac}}$ & $4.13^{\mathrm{Ac}}$ & $4.08^{\mathrm{Ac}}$ \\
\hline 21 & $4.17^{\mathrm{Ad}}$ & $4.13^{\mathrm{ABd}}$ & $4.08^{\mathrm{ABCd}}$ & $4.03^{\mathrm{ABCd}}$ & $4.07^{\mathrm{ABCd}}$ & $4.02^{\mathrm{ABCd}}$ & $4.00^{\mathrm{ABCd}}$ & $3.95^{\mathrm{BCd}}$ & $3.99^{\mathrm{ABCd}}$ & $3.94^{\mathrm{Cd}}$ \\
\hline
\end{tabular}

$\mathbf{C}_{1}$ : Control without oat., $\mathbf{C}_{2}$ : Control with $1 \%$ oat., $\mathbf{T}_{1}: 7.5 \%$ Red grape juice $+1.5 \%$ B. breve $+1 \%$ oat., $\mathbf{T}_{2}: 10 \%$ Red grape juice $+1.5 \%$ B. breve $+1 \%$ oat., $\mathbf{T}_{3}: 7.5 \%$ Red grape juice $+1.5 \%$ L. plantarum $+1 \%$ oat., $\mathbf{T}_{4}: 10 \%$ Red grape juice $+1.5 \%$ L. plantarum $+1 \%$ oat., $\mathbf{T}_{5}: 7.5 \%$ Apricot juice $+1.5 \%$ B. breve $+1 \%$ oat., $\mathbf{T}_{6}: 10 \%$ Apricot juice $+1.5 \%$ B. breve $+1 \%$ oat., $\mathbf{T}_{7}: 7.5 \%$ Apricot juice $+1.5 \%$ L. plantarum $+1 \%$ oat., $\mathbf{T}_{8}: 10 \%$ Apricot juice $+1.5 \%$ L. plantarum $+1 \%$ oat.A, B, $\mathbf{C}$ : Means with same letter among treatments in the same storage period are not significantly different $(\mathrm{p} 0.05<), \mathbf{a}, \mathbf{b}, \mathbf{c}$ : Means with same letter for same treatment during storage period are not significantly different $(\mathrm{p} 0.05<)$.

Egypt. J. Food Sci. 48, No.1 (2020) 
The protein contents of fresh yoghurt treatments were significantly different $(\mathrm{p} 0.05<)$. The results indicated that the controls yoghurt had higher protein content specially $\mathrm{C}_{2}$, as oat has more protein than milk. The protein content was decreased in the fruit-flavoured treatments with addition of fruit juices because fruit juices contain lower protein than milk. Increasing the amount of the fruit juices significantly decreased the protein percentage. The red grape yoghurt treatments gained lower protein content compared with apricot yoghurt treatments because the red grape has less protein content than apricot. Similar results were reported by Roy et al. (2015), Mbaeyi-Nwaoha et al. (2017) and Desouky (2018). During cold storage, there were significantly increase in the protein content for all yoghurt treatments and controls to reach the highest value for $\mathrm{C}_{2}$. The treatment $\mathrm{T}_{2}$ gained the lowest protein value at the end of storage period (21 days). These results agree with those of Hassanein et al. (2014) and Kermiche et al. (2018). The fat content significantly increased till the end of storage period ( 21 days) and scored the minimum value for treatment $\mathrm{T}_{4}$ to maximum value for $\mathrm{C}_{2}$. These results agree with those obtained by Abdalla et al. (2015) and El-Alfy et al. (2018). According to the obtained data, it can be noticeable that the fat content was lower in the yoghurt treatments enriched with fruit juices than the controls $\left(\mathrm{C}_{1}\right.$ and $\left.\mathrm{C}_{2}\right)$, Increasing the amount of fruit juices were significantly declined the fat percent for all yoghurt treatments because the fruit juices contain low fat content then milk. These findings agree with those given by Dey et al. (2014), Sengupta et al. (2014), Raut et al. (2015) and Matter et al. (2016) which confirmed these results. The ash content of the apricot fruit drinkable yoghurt treatments had significantly higher ash content compared to other yoghurt treatments, when fresh and during storage. This was related to that apricot is rich source of ash content. Similar observations are reported by Farahat \& El-Batawy (2013), Hamad et al. (2017) and Salih \& Abdalla (2017). During cold storage period, there was significant increase in ash content of all tested drinkable yoghurt after 21 days of storage. This could be attributed to the loss of some moisture contents from the samples during storage period. Similar results are reported by Gunawardhana \& Dilrukshi (2016) and Hammad (2019).
Carbohydrates content (CHO) was significantly decreased within progress of cold storage period of all yoghurt treatments reaching the lowest values at the end of storage ( 21 days). This decrease caused by the carbohydrate's hydrolysis, which attributed to the growth and activity of lactic acid bacteria and acid development that increased greatly during storage. These findings are in harmony with the results obtained by Kauser et al. (2011) and Hammad (2019).

The yoghurt treatments enriched with fruit juices had significantly higher $\mathrm{CHO}$ percentages when fresh and during storage period compared with the controls (without fruit juices). The $\mathrm{CHO}$ content increased with increase in the concentration of fruit juices in the fruitflavoured drinkable yoghurt treatments because red grape and apricot contains more sugar than milk (Hossain et al., 2012, Hassanein et al., 2014, Matter et al., 2016 and Mbaeyi-Nwaoha et al., 2017).

Titratable acidity (T.A) of fresh yoghurt recorded the lowest value for $\mathrm{C} 1$ and the highest value for T8. With the progress of storage period to 21 days, there was a significant increase of the acidity values to be recorded $0.88 \%$ as lowest value for $\mathrm{C} 1$ and $1.14 \%$ as highest value for T8. The increase of acidity can be related to the growth of lactic acid bacteria, which consume the carbohydrate, and the consequent increase of lactic and acetic acids as metabolism by products. These findings agree with AbdelGaleele et al. (2013), Hamad et al. (2017) and El-Alfy et al. (2018). In general, the fruit juices addition significantly increase the yoghurt acidity compared to the controls when fresh or along the cold storage, due to the nature of fruit acidity, which contains more acidity than milk, with consider that apricot had higher acidity than red grape.

This increase of acidity also, might be related to the high sugars contents in red grape and apricot juices which are more easily utilized by starter bacterial culture and resulted in higher acidity. Increasing the addition of fruit juice into yoghurt significantly increased the titratable acidity. Similar observations were reported by Farahat \& El-Batawy (2013), Raut et al. (2015) and Meenakshi et al. (2018). 
The $\mathrm{pH}$ values revealed an opposite trend to that observed for titratable acidity measurements of the fruit-flavoured drinkable yoghurt, i.e., as the acidity increased, the $\mathrm{pH}$ decreased (Table 2). The $\mathrm{pH}$ values of fresh yoghurt treatments were significantly declined among the storage up to 21 days. This may be due to fermentation of carbohydrates, which produces organic acids and amino acids during fermentation and storage periods. These outcomes are consistent with those of Karaca et al. (2012), Güler-Akin et al. (2016) and Narayana \& Gupta (2018).

\section{Soluble indices of fruit-flavoured drinkable yoghurt \\ The soluble indices of fruit-flavoured} drinkable yoghurt are shown in Table 3. The water-soluble nitrogen contents (WSN) of fresh probiotic yoghurt treatments were gradually and significantly increased in various yoghurt treatments as storage period advanced.

The values of WSN were ranged from $0.191 \%$ for $\mathrm{C}_{1}$, to $0.258 \%$ for $\mathrm{T} 4$ at the end of storage period. These may be due to proteases and peptidases released from starter culture, which resulted in higher proteolysis (Ismail et al., 2016). The results indicated that increasing of WSN levels during storage were higher in enriched treatments than controls. These results might be interpreted to mean that fruit juice components have simulative effect on yoghurt microorganisms. The results are in harmony with those obtained with Ismail (2015) and Hamad et al. (2017). The total volatile fatty acids content (TVFA) were pronounced significant differences among fresh yoghurt treatments. All of yoghurt treatments recorded TVFA values higher than the controls, which indicated that TVFA contents were affected by the type and level of fruit juice. The high level of enriched red grape juice 10 $\%$ (treatment $\mathrm{T}_{2}$ and $\mathrm{T}_{4}$ ) recorded the highest TVFA values 7.50 and $7.93 \mathrm{ml} 0.1 \mathrm{~N} \mathrm{NaOH} / 100 \mathrm{~g}$, in the same sequence. These results may be attributed to the simulative effect of some compounds of fruit juices on starter bacteria. TVFA values gradually increased in all treatments up to the end of the storage period. The increasing rate was higher in the fruit-flavoured treatments, especially red grape yoghurt. During the storage period, volatile fatty acids are produced by the transformation of lactose, and amino acids and lipid metabolism by the metabolic activity of starter cultures. These findings agree with the results obtained by (Karaca et al., 2012, Abdel-Galeele et al., 2013 and Hammad, 2019).
Acetaldehyde and diacetyl contents of fresh treatments were recorded the highest value of $29.16 \mathrm{ppm}$ for T8. These values of the acetaldehyde content significantly decreased during storage (21 days) to be the lowest value of $24.10 \mathrm{ppm}$ for T8.

The reduction in acetaldehyde contents may be due to the dehydrogenase activity of some lactic acid organisms to oxidize acetaldehyde into acetate and ethanol at lower $\mathrm{pH}$ values. These results are in harmony with that reported by Karaca et al. (2012) and Abdel-Galeele et al. (2013). Diacetyl content took an opposite trend to that of acetaldehyde content, thus with the increase during storage period, the diacetyl content significantly increased (Table 3). The obtained results match with those obtained by ElAlfy et al. (2018). It could be noticed that fruitflavoured drinkable yoghurt had significant higher acetaldehyde and diacetyl contents compared with the controls, treatment $\left(\mathrm{T}_{4}\right)$ gained the highest values of acetaldehyde and diacetyl when fresh and throughout the interval of storage periods (Mangia et al., 2014 and Narayana \& Gupta, 2018).

\section{Rheological properties of fruit-flavoured drinkable yoghurt}

Rheological properties of fruit-flavoured drinkable yoghurt when fresh and during storage were illustrated in Fig. 1. The apparent viscosity values (cP) of fruit-flavoured drinkable yoghurt shown in Fig $(1 \mathrm{~A})$ indicated that the values of fresh treatments were ranged from $55.07 \mathrm{cP}$ for $\mathrm{C} 1$, to $208.03 \mathrm{cP}$ for $\mathrm{T}_{8}$. During storage period, the viscosity values in all drinkable yoghurt increased significantly to record a range of 127.35 to 333.82 $\mathrm{cP}$ at 21 days. It could be related to the increase of total solids content and titratable acidity within the storage. These findings agree with Karaca et al. (2012), Silva et al. (2017) and Desouky (2018). Comparing the viscosity of different fruitflavoured drinkable yoghurt treatments, all the treatments observed significantly increase of this parameter and these parameter values increased with increasing fruit juices level. In addition, the viscosity of apricot treatments had higher values than other treatments, particularly treatment $T_{8}$. Meanwhile, the control characterized with the lowest viscosity values throughout the storage period. It could be commonly attributed to the high content of solids and fibers in fruit juices. These results agree with Kavas \& Kavas (2016), Saranyambiga et al. (2017) and Subhashini et al. (2018). 
TABLE 3. Soluble indices of fruit-flavoured drinkable yoghurt when fresh and during storage at $\sim 5^{\circ} \mathrm{C}$ up to 21 days.

\begin{tabular}{|c|c|c|c|c|c|c|c|c|c|c|}
\hline $\begin{array}{l}\text { Storage } \\
\text { period } \\
\text { (days) }\end{array}$ & $\mathrm{C}_{1}$ & $\mathrm{C}_{2}$ & $\mathbf{T}_{1}$ & $\mathbf{T}_{2}$ & $\mathbf{T}_{3}$ & $\mathbf{T}_{4}$ & $\mathbf{T}_{5}$ & $\mathbf{T}_{6}$ & $\mathbf{T}_{7}$ & $\mathbf{T}_{8}$ \\
\hline & \multicolumn{10}{|c|}{ Water soluble nitrogen (WSN \%) } \\
\hline 7 & $0.175^{\mathrm{Dc}}$ & $0.190^{\mathrm{Cc}}$ & $0.203^{\mathrm{Bc}}$ & $0.221^{\mathrm{Ac}}$ & $0.217^{\mathrm{Ac}}$ & $0.225^{\mathrm{Ac}}$ & $0.195^{\mathrm{BCc}}$ & $0.198^{\mathrm{BCc}}$ & $0.219^{\mathrm{Ac}}$ & $0.221^{\mathrm{Ac}}$ \\
\hline 14 & $0.186^{\mathrm{Eb}}$ & $0.198^{\mathrm{DEb}}$ & $0.215^{\mathrm{BCDb}}$ & $0.240^{\mathrm{Ab}}$ & $0.229^{\mathrm{ABb}}$ & $0.241^{\mathrm{Ab}}$ & $0.201^{\mathrm{CDEb}}$ & $0.211^{\mathrm{BCDb}}$ & $0.225^{\mathrm{ABCb}}$ & $0.232^{\mathrm{ABb}}$ \\
\hline Fresh & $5.82^{\mathrm{Ca}}$ & $6.43^{\mathrm{BCa}}$ & $7.21^{\mathrm{ABa}}$ & $7.50^{\mathrm{ABa}}$ & $7.42^{\mathrm{ABa}}$ & $7.93^{\mathrm{Aa}}$ & $6.91^{\mathrm{CDa}}$ & $7.12^{\mathrm{ABa}}$ & $7.24^{\mathrm{ABa}}$ & $7.37^{\mathrm{ABa}}$ \\
\hline 7 & $6.53^{\mathrm{Ea}}$ & $7.72^{\mathrm{Da}}$ & $9.08^{\mathrm{Ca}}$ & $9.90^{\mathrm{BCa}}$ & $10.15^{\mathrm{Ba}}$ & $11.11^{\mathrm{Aa}}$ & $8.73^{\mathrm{CDa}}$ & $11.30^{\mathrm{Aa}}$ & $9.41^{\mathrm{Ca}}$ & $10.06^{\mathrm{Ba}}$ \\
\hline 14 & $7.32^{\mathrm{Ea}}$ & $8.56^{\mathrm{DEa}}$ & $10.66^{\mathrm{Da}}$ & $11.73^{\mathrm{Ca}}$ & $12.70^{\mathrm{Ca}}$ & $13.31^{\mathrm{BCa}}$ & $9.93^{\mathrm{ABa}}$ & $10.33^{\mathrm{Aa}}$ & $10.13^{\mathrm{Aa}}$ & $11.90^{\mathrm{Aa}}$ \\
\hline 21 & $7.90^{\mathrm{Ea}}$ & $9.34^{\mathrm{DEa}}$ & $12.25^{\mathrm{Da}}$ & $12.92^{\mathrm{Ca}}$ & $13.74^{\mathrm{Ca}}$ & $14.52^{\mathrm{BCa}}$ & $11.15^{\mathrm{ABa}}$ & $11.7^{\mathrm{Aa}}$ & $12.37^{\mathrm{Aa}}$ & $13.11^{\mathrm{Aa}}$ \\
\hline 14 & $16.92^{\mathrm{Fc}}$ & $18.15^{\mathrm{Fc}}$ & $21.83^{\mathrm{DEc}}$ & $25.27^{\mathrm{ABc}}$ & $24.56^{\mathrm{BCc}}$ & $26.04^{\mathrm{ABc}}$ & $20.40^{\mathrm{Ec}}$ & $21.92^{\mathrm{DEc}}$ & $23.45^{\mathrm{CDc}}$ & $26.58^{\mathrm{Ac}}$ \\
\hline 21 & $16.11^{\mathrm{Gd}}$ & $17.63^{\mathrm{Fd}}$ & $20.12^{\mathrm{Dd}}$ & $23.51^{\mathrm{Bd}}$ & $22.47^{\mathrm{Cd}}$ & $25.13^{\mathrm{Ad}}$ & $19.94^{\mathrm{Ed}}$ & $20.23^{\mathrm{Dd}}$ & $22.96^{\mathrm{Cd}}$ & $24.10^{\mathrm{Ad}}$ \\
\hline \multicolumn{11}{|c|}{ Diacetyl (ppm) } \\
\hline Fresh & $10.23^{\mathrm{Fd}}$ & $12.64^{\mathrm{Ed}}$ & $15.11^{\mathrm{CDd}}$ & $17.13^{\mathrm{ABd}}$ & $16.05^{\mathrm{BCd}}$ & $18.27^{\mathrm{Ad}}$ & $13.97^{\mathrm{DEd}}$ & $15.21^{\mathrm{CDd}}$ & $14.25^{\mathrm{Dd}}$ & $16.11^{\mathrm{BCd}}$ \\
\hline 7 & $11.07^{\mathrm{Hc}}$ & $13.55^{\mathrm{Gc}}$ & $16.69^{\mathrm{CDEc}}$ & $18.44^{\mathrm{Bc}}$ & $17.78^{\mathrm{BCc}}$ & $20.08^{\mathrm{Ac}}$ & $14.78^{\mathrm{Fc}}$ & $16.24^{\mathrm{DEc}}$ & $15.66^{\mathrm{EFc}}$ & \\
\hline 14 & $11.94^{\mathrm{Gb}}$ & $14.06^{\mathrm{Fb}}$ & $17.55^{\mathrm{Db}}$ & $19.73^{\mathrm{Bb}}$ & $18.46^{\mathrm{Cb}}$ & $21.34^{\mathrm{Ab}}$ & $16.02^{\mathrm{Eb}}$ & $17.77^{\mathrm{Db}}$ & $16.45^{\mathrm{Eb}}$ & $18.67^{\mathrm{Cb}}$ \\
\hline 21 & $12.25^{\mathrm{Ga}}$ & $15.29^{\mathrm{Fa}}$ & $18.58^{\mathrm{Da}}$ & $21.48^{\mathrm{Ba}}$ & $19.67^{\mathrm{Ca}}$ & $23.28^{\mathrm{Aa}}$ & $17.02^{\mathrm{Ea}}$ & $18.45^{\mathrm{Da}}$ & $17.36^{\text {Ea }}$ & $19.42^{\mathrm{Ca}}$ \\
\hline
\end{tabular}

$\mathbf{C}_{1}$ : Control without oat., $\mathbf{C}_{2}$ : Control with $1 \%$ oat., $\mathbf{T}_{1}: 7.5 \%$ Red grape juice $+1.5 \%$ B. breve $+1 \%$ oat., $\mathbf{T}_{2}: 10 \%$ Red grape juice $+1.5 \%$ B breve $+1 \%$ oat., $\mathbf{T}_{3}: 7.5 \%$ Red grape juice $+1.5 \%$. plantarum $+1 \%$ oat., $\mathbf{T}_{4}: 10 \%$ Red grape juice $+1.5 \% L$. plantarum $+1 \%$ oat., $\mathbf{T}_{5}: 7.5 \%$ Apricot juice $+1.5 \%$ B. breve $+1 \%$ oat., $\mathbf{T}_{6}: 10 \%$ Apricot juice $+1.5 \%$ B. breve $+1 \%$ oat., $\mathbf{T}_{7}$ : $7.5 \%$ Apricot juice $+1.5 \%$ L. plantarum $+1 \%$ oat., $\mathbf{T}_{\mathbf{8}}: 10 \%$ Apricot juice $+1.5 \%$ L. plantarum $+1 \%$ oat.A, $\mathbf{B}, \mathbf{C}$ : Means with same letter among treatments in the same storage period are not significantly different $(\mathrm{p} 0.05<), \mathbf{a}, \mathbf{b}, \mathbf{c}$ : Means with same letter for same treatment during storage period are not significantly different ( $0.05<$ ). 
A)

घC1 घC2 घT1 घT2 घT3 घT4 घT5 घT6 घT7 घT8

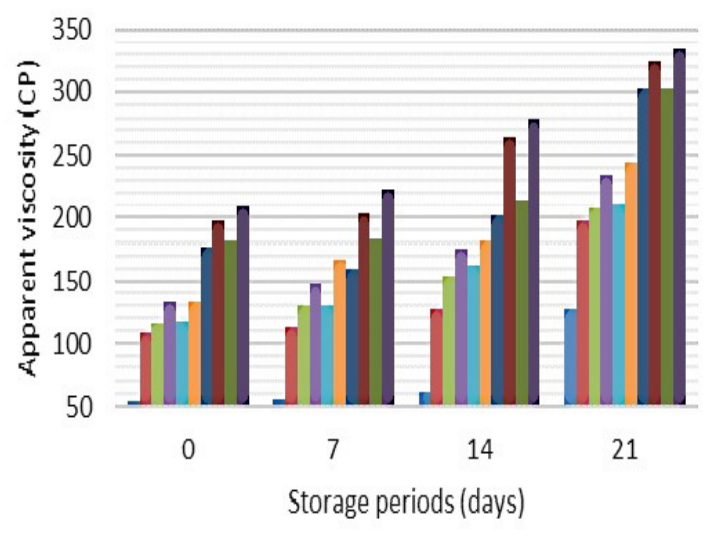

B)

घ1 aC2 घT1 घT2 घT3 घT4 घT5 घT6 घT7 घT8

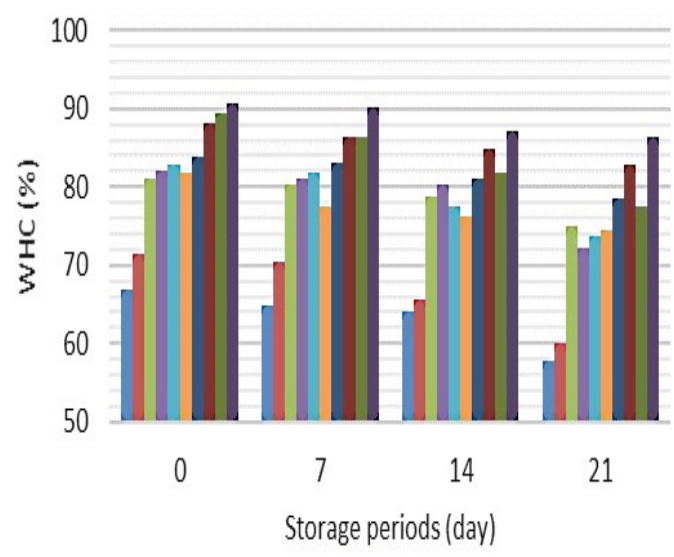

Fig. 1. Rheologicalpropertiesoffruit-flavoureddrinkableyoghurtwhenfreshandduringstorageat $\sim 5^{\circ} \mathrm{Cupto}$ 21 days. (A): Apparent viscosity (B): Water holding capacity.

The water holding capacity (WHC) of fresh drinkable yoghurt treatments were ranged from 66.88 to $90.81 \%$ for $\mathrm{C}_{1}$, and $\mathrm{T}_{8}$, consequently (Fig. 1B). During storage, WHC gradually decreased significantly for all treatments which extended with storage period to be ranged from 57.82 to $86.4 \%$ for treatments $\mathrm{C}_{1}$, and $\mathrm{T}_{8}$, respectively. The decrease of WHC during storage could be due to acid development in yoghurt treatments. The trend of results is in accordance with Silva et al. (2017) and Hammad (2019). The WHC was exhibited to be significantly higher in the fruit-flavoured yoghurt treatments and exhibited greater ability to bind water compared to control yoghurt throughout the storage period. This may be probably due to the higher percentage of total solids and crude fibers. The higher WHC was obtained for yoghurt made using apricot juice (high fiber), especially $\left(\mathrm{T}_{4}\right)$. These data are confirmed by Sengupta et al. (2014), Kermiche et al. (2018) and Narayana \& Gupta (2018).

The results in Table 4 indicated that all probiotic fruit-flavoured drinkable yoghurt exhibited a high and statistically significant increase in the total phenolic content (TPC) compared to the controls and they increased by increasing the percentage of added fruit juices. $\left(\mathrm{T}_{4}\right)$ yoghurt showed the highest content due to the high levels of phenolic compounds. These findings agree with Marchiani et al. (2016) and Desouky (2018). Concerning total flavonoids content TFC values, the same trend of results was noticed. TFC increased with the increase of the added fruit juices, chiefly red grape juice (Abou El Samhet al., 2013 and Hammad, 2019). From the obtained data, it was found that TPC and TFC gradually and significantly decreased during the storage period for all yoghurt treatments and it was more noticeable for $\mathrm{C}_{1}$ (without fruit juice or oat). This might harm due to cold storage, which attributed to transformation of these compounds and decreased stability. Similar results are reported by Mansouri et al. (2005), Ali (2018) and El-Alfy et al. (2018).

The antioxidant activity (AA), determined in the fruit-flavoured drinkable yoghurt when fresh and during cold storage period up to 21 days (Table 4). The AA raised as the level of fruit juices heightened. Logically, the higher contents of total phenolic and flavonoids compounds are the higher AA percentages so that fruit-flavoured drinkable yoghurt contained higher antioxidant activity percentages than those found in the controls. Yoghurt made with red grape juice gained higher $\mathrm{AA}$, and treatment $\left(\mathrm{T}_{4}\right)$ had the highest content. This could be associated with high bioactive compounds released in supplemented yoghurt, with antioxidant properties. Similar trend was reported by Ismail et al. (2016), Hamad et al. (2017) and Ali (2018). The AA significantly decreased in all yoghurt treatments through the storage period, being lower in controls rather than supplemented yoghurt treatments, due to the cold storage of the fruit-flavoured drinkable yoghurt. Similar results were obtained by Kumar \& Kumar (2016), Ahmed (2017) and Desouky (2018). 
TABLE 4. Total phenolic (TPC), total flavonoids (TFC) contents and antioxidant activity assay (AA) of fruitflavoured drinkable yoghurt when fresh and during storage at $\sim 5^{\circ} \mathrm{C}$ up to 21 days.

\begin{tabular}{|c|c|c|c|c|c|c|c|c|c|c|}
\hline \multirow{2}{*}{$\begin{array}{c}\text { Storage } \\
\text { period } \\
\text { (days) }\end{array}$} & $\mathrm{C}_{1}$ & $\mathrm{C}_{2}$ & $\mathrm{~T}_{1}$ & $\mathbf{T}_{2}$ & $\mathbf{T}_{3}$ & $\mathbf{T}_{4}$ & $\mathbf{T}_{5}$ & $\mathbf{T}_{6}$ & $\mathbf{T}_{7}$ & $\mathbf{T}_{8}$ \\
\hline & \multicolumn{10}{|c|}{ TPC (mg GAE/100g) } \\
\hline Fresh & $10.18^{\mathrm{Da}}$ & $13.38^{\mathrm{Ca}}$ & $20.00^{\mathrm{Aa}}$ & $20.63^{\mathrm{Aa}}$ & $20.22^{\mathrm{Aa}}$ & $20.94^{\mathrm{Aa}}$ & $17.32^{\mathrm{Ba}}$ & $19.37^{\mathrm{ABa}}$ & $19.09^{\mathrm{ABa}}$ & $20.05^{\mathrm{Aa}}$ \\
\hline 7 & $8.50^{\mathrm{Eb}}$ & $11.11^{\mathrm{Db}}$ & $17.85^{\mathrm{ABb}}$ & $18.52^{\mathrm{Ab}}$ & $16.98^{\mathrm{BCb}}$ & $18.45^{\mathrm{Ab}}$ & $16.04^{\mathrm{Cb}}$ & $16.58^{\mathrm{BCb}}$ & $17.11^{\mathrm{BCb}}$ & $17.25^{\mathrm{ABCb}}$ \\
\hline 14 & $7.47^{\mathrm{Fc}}$ & $9.58^{\mathrm{Ec}}$ & $15.78^{\mathrm{Bc}}$ & $16.58^{\mathrm{Ac}}$ & $15.05^{\mathrm{Bc}}$ & $16.89^{\mathrm{Ac}}$ & $13.55^{\mathrm{Dc}}$ & $14.50^{\mathrm{Cc}}$ & $14.01^{\mathrm{Cc}}$ & $11.53^{\mathrm{Cc}}$ \\
\hline \multirow[t]{2}{*}{21} & $5.60^{\mathrm{Gd}}$ & $8.45^{\mathrm{Fd}}$ & $13.54^{\mathrm{BCd}}$ & $14.14^{\mathrm{Ad}}$ & $13.98^{\mathrm{Bd}}$ & $15.12^{\mathrm{Ad}}$ & $10.18^{\mathrm{Ed}}$ & $12.98^{\mathrm{Cd}}$ & $11.08^{\text {Dd }}$ & $13.12^{\mathrm{Cd}}$ \\
\hline & \multicolumn{10}{|c|}{ TFC (mg QE/100g) } \\
\hline Fresh & $5.38^{\mathrm{Da}}$ & $6.33^{\mathrm{Da}}$ & $9.31^{\mathrm{BCa}}$ & $11.31^{\mathrm{ABa}}$ & $9.53^{\mathrm{BCa}}$ & $12.27^{\mathrm{Aa}}$ & $8.54^{\mathrm{Ca}}$ & $9.22^{\mathrm{Ca}}$ & $8.19^{\mathrm{Ca}}$ & $10.02^{\mathrm{BCa}}$ \\
\hline 7 & $4.19^{\mathrm{Db}}$ & $5.67^{\mathrm{Cb}}$ & $8.18^{\mathrm{Bb}}$ & $9.75^{\mathrm{Ab}}$ & $8.61^{\mathrm{Bb}}$ & $10.35^{\mathrm{Ab}}$ & $7.70^{\mathrm{Bb}}$ & $7.88^{\mathrm{Bb}}$ & $7.89^{\mathrm{Bb}}$ & $9.71^{\mathrm{Ab}}$ \\
\hline 14 & $3.91^{\mathrm{Fc}}$ & $5.08^{\mathrm{Ec}}$ & $7.32^{\mathrm{Cc}}$ & $8.73^{\mathrm{Bc}}$ & $7.15^{\mathrm{Cc}}$ & $9.49^{\mathrm{Ac}}$ & $6.71^{\mathrm{Dc}}$ & $7.27^{\mathrm{Cc}}$ & $9.02^{\mathrm{Cc}}$ & $8.39^{\mathrm{Bc}}$ \\
\hline 21 & $3.04^{\mathrm{Fd}}$ & $4.40^{\mathrm{Ed}}$ & $6.37^{\mathrm{CDd}}$ & $7.16^{\mathrm{BCd}}$ & $6.93^{\mathrm{Cd}}$ & $8.66^{\mathrm{Ad}}$ & $5.87^{\mathrm{Dd}}$ & $6.62^{\mathrm{Cd}}$ & $6.07^{\mathrm{Cd}}$ & $7.25^{\mathrm{Bd}}$ \\
\hline \multicolumn{11}{|c|}{ Antioxidant activity (\%) } \\
\hline Fresh & $18.87^{\mathrm{Ca}}$ & $21.25^{\mathrm{BCa}}$ & $33.20^{\mathrm{ABa}}$ & $34.61^{\mathrm{Aa}}$ & $33.36^{\mathrm{ABa}}$ & $35.12^{\mathrm{Aa}}$ & $29.23^{\mathrm{Ba}}$ & $30.11^{\mathrm{Ba}}$ & $30.42^{\mathrm{Ba}}$ & $31.58^{\mathrm{ABa}}$ \\
\hline 7 & $16.41^{\mathrm{Bb}}$ & $18.52^{\mathrm{Bb}}$ & $30.12^{\mathrm{Ab}}$ & $30.87^{\mathrm{Ab}}$ & $29.87^{\mathrm{Ab}}$ & $30.01^{\mathrm{Ab}}$ & $26.25^{\mathrm{Ab}}$ & $27.65^{\mathrm{Ab}}$ & $28.98^{\mathrm{Ab}}$ & $28.15^{\mathrm{Ab}}$ \\
\hline 14 & $14.80^{\mathrm{Cc}}$ & $15.94^{\mathrm{Cc}}$ & $25.54^{\mathrm{ABc}}$ & $26.63^{\mathrm{Ac}}$ & $25.66^{\mathrm{Acc}}$ & $26.02^{\mathrm{Ac}}$ & $23.25^{\mathrm{Bc}}$ & $24.70^{\mathrm{ABc}}$ & $25.06^{\mathrm{ABc}}$ & $24.94^{\mathrm{ABc}}$ \\
\hline 21 & $11.55^{\text {Dd }}$ & $13.78^{\text {Dd }}$ & $22.89^{\mathrm{ABCd}}$ & $23.58^{\mathrm{ABd}}$ & $23.45^{\mathrm{ABd}}$ & $24.12^{\mathrm{ABd}}$ & $20.65^{\mathrm{Cd}}$ & $21.58^{\mathrm{BCd}}$ & $22.58^{\mathrm{ABd}}$ & $22.08^{\mathrm{ABd}}$ \\
\hline
\end{tabular}

$\mathbf{C}_{1}$ : Control without oat., $\mathbf{C}_{2}$ : Control with $1 \%$ oat., $\mathbf{T}_{1}: 7.5 \%$ Red grape juice $+1.5 \%$ B. breve $+1 \%$ oat., $\mathbf{T}_{2}$ : $10 \%$ Red grape juice $+1.5 \%$ B. breve $+1 \%$ oat., $\mathbf{T}_{3}: 7.5 \%$ Red grape juice $+1.5 \%$ L. plantarum $+1 \%$ oat., $\mathbf{T}_{4}$ : $10 \%$ Red grape juice $+1.5 \%$ L plantarum $+1 \%$ oat., $\mathbf{T}_{5}: 7.5 \%$ Apricot juice $+1.5 \%$ B. breve $+1 \%$ oat., $\mathbf{T}_{6}$ : $10 \%$ Apricot juice $+1.5 \%$ B. breve $+1 \%$ oat., $\mathbf{T}_{7}: 7.5 \%$ Apricot juice $+1.5 \%$ L. plantarum $+1 \%$ oat., $\mathbf{T}_{8}: 10 \%$ Apricot juice $+1.5 \%$ L. plantarum $+1 \%$ oat.A, $\mathbf{B}, \mathbf{C}$ : Means with same letter among treatments in the same storage period are not significantly different $(\mathrm{p} 0.05<), \mathbf{a}, \mathbf{b}, \mathbf{c}$ : Means with same letter for same treatment during storage period are not significantly different $(\mathrm{p} 0.05<)$.

\section{Microbiological aspects of fruit-flavoured drinkable yoghurt}

Total bacterial counts (TBC) were shown in (Table 5). The TBC were increased up to 7 days, then, the counts gradually declined to the end of storage period. The decline of TBC through cold storage period is attributed to the decrease of $\mathrm{pH}$ (post-acidification) and the accumulation of organic acids because of growth and fermentation. Similar trend was obtained by Hamad (2017) and Desouky (2018). Yoghurt treatments supplemented with various concentrations of fruit juices had higher numbersof TBC compared to that in controls when fresh and along storage period, as the level of fruit juices supplementation increased the viability of these bacteria improved further. This may be due to juices encouraged the growth bacteria because of their higher nutritive values (Hossain et al., 2012, Hassanein et al., 2014 and Ismail et al., 2016). Lactic acid bacterial counts (LAB) of the fresh treatments were raised slowly during the storage up to 7 days then there were pronounced reduction in viable counts until the end of storage period. 
This decrease may be due to the sensitivity of starter culture to the raised acidity and secreted of some other metabolites which reduced the counts of bacteria. These results agree with those given by Ali (2018) and El-Alfy et al. (2018). The obtained results confirmed that utilization of fruit juices in drinkable yoghurt making increased the numbers of LAB in fresh product and along storage periods. Among treatments, $\mathrm{T}_{4}$ (with $10 \%$ red grape) and the control $\left(\mathrm{C}_{1}\right)$ had the highest and the lowest count. This may be referring to the starter culture which activated by adding fruit juice to yoghurt becausefruit is richer in solids (sugars, proteins, etc.) compared to controls. Therefore, these compounds have probably stimulated the development of lactic acid bacteria. These findings are in a harmony with the results obtained by Do Espirito Santo et al. (2010), Mangia et al. (2014) and Kermiche et al. (2018). Streptococcus thermophilus counts were gradually increased in all treatments till the $7^{\text {th }}$ day of cold storage, which could be due to residual activity during this period, then there were decrease slowly up to the end of the storage period. This may be due to the stimulated growth of Streptococcus species by essential amino acids occurred during 7 days of storage. After 7 days, lactic acid could make the environment unfavorable for the growth of Streptococcus species. These results agree with those obtained by Abdel-Galeele et al. (2013) and Güler-Akin et al. (2016). The count of Str. thermophilus of all treatments made with fruit juices had higher count compared to the controls at fresh and through the storage period. The greatest counts of Str. thermophillus were observed in the treatments contained $10 \%$ red grape (treatment $\mathrm{T}_{2}$ and $\mathrm{T}_{4}$ ), whereas their richness in total sugars which enhance the growth of starter cultures. Some observations were found by Ismailet al. (2016) and Hamad et al. (2017).

Bifidobacterium ssp. and Lactobacillus plantarum counts are shown in Table 5. During the cold storage, the Bifidobacterium ssp counts increased likewise the L. plantarum counts were increased up to 7 days of storage and then decreased till the end of storage period. This decrease may be due to acid injury to the organisms.

These findings are in matching with those revealed by Ismail (2015) and Hammad (2019). Although, the decline of Bifidobacterium and $L$. plantarum counts throughout cold storage, their numbers still above the recommended level until the end of storage. As they are adequate to achieve therapeutic effects $\left(10^{6}-10^{7} \mathrm{cfu} / \mathrm{ml}\right)$.

On the other hand, adding fruit juices and oat to drinkable yoghurt had positive effect on the probiotic counts either Bifidobacterium or Lactobacillus plantarum, especially red grape juice, increase the level of fruit juices enhance the growth of the probiotic as a result of increased metabolism of fructose and malic acid derived from fruit which stimulate the bacterial growth.

Also, addition of oat to drinkable yoghurt stimulated the growth of probiotic bacteria where oat fibers serve as prebiotics. These results are in accordance with Hamad et al. (2017) and Silva et al. (2017). Yeast \& moulds, coliform and sporeforming counts were not detected in all treatments either fresh or along the storage period. This may be due to the efficient heat treatment of the different yoghurt milks $\left(85^{\circ} \mathrm{C}\right.$ for $\left.10 \mathrm{~min}\right)$, the high hygienic conditions during making and storage of yoghurt. In addition, the antimicrobial agents, and the development of the acidity in yoghurt during storage contribute in prolonging of shelf life of the product. The obtained data are in a harmony with those of Matter et al. (2016) and Meenakshi et al. (2018).

\section{Sensory evaluation of fruit-flavoured drinkable yoghurt}

The results in Fig. 2 revealed that average flavor score for all fresh yoghurt treatments recorded the range of 40.9 , and 47.6 for $\mathrm{C}_{1}$ and $\mathrm{T}_{8}$, respectively. With progress of storage period, there was gradual improvement in these values to be ranged from 41.5 , to 48.1 after the $7^{\text {th }}$ day, in the previous order. While the progress of cold storage significantly led to decrease in flavour values reaching the lowest points at 21 days, as ranging from 38.2 to 47.9 . This could be associated with development of acidity and decrease in acetaldehyde contents of the yoghurt. It can be observed that the fruit juices incorporation significantly enhanced the flavour of yoghurt samples. $\mathrm{T}_{4}$ followed by $\mathrm{T}_{3}$ gained the highest flavour points, while $\mathrm{C}_{1}$ followed by $\mathrm{C}_{2}$ recorded the minimum score of flavour. In respect to the average score points of body \& texture of all produced fruit-flavoured drinkable yoghurt. The average score became slightly high after 7 days of storage and then significantly decline till the end of storage period to reach the range of 30.8 for $\mathrm{C} 1$ to 36.4 for $\mathrm{T} 8$ after 21 days of storage (Fig. 2). 
TABLE 5. Microbiological aspects $(\log \mathrm{efu} / \mathrm{ml})$ of fruit-flavoured drinkable yoghurt when fresh and during storage at $\sim 5^{\circ} \mathrm{C}$ up to 21 days.

\begin{tabular}{|c|c|c|c|c|c|c|c|c|c|c|}
\hline \multirow{2}{*}{$\begin{array}{l}\text { Storage } \\
\text { period } \\
\text { (days) }\end{array}$} & $\mathrm{C}_{1}$ & $\mathrm{C}_{2}$ & $\mathbf{T}_{1}$ & $\mathbf{T}_{2}$ & $\mathbf{T}_{3}$ & $\mathbf{T}_{4}$ & $\mathbf{T}_{5}$ & $\mathbf{T}_{6}$ & $\mathbf{T}_{7}$ & $\mathbf{T}_{8}$ \\
\hline & \multicolumn{10}{|c|}{ Total bacterial count (TBC) } \\
\hline Fresh & 8.39 & 8.45 & 8.66 & 8.68 & 8.70 & 8.77 & 8.51 & 8.58 & 8.60 & 8.65 \\
\hline 7 & 8.63 & 8.73 & 8.87 & 8.91 & 8.91 & 8.96 & 8.79 & 8.82 & 8.87 & 8.88 \\
\hline 14 & 8.44 & 8.66 & 8.76 & 8.80 & 8.81 & 8.85 & 8.69 & 8.74 & 8.74 & 8.76 \\
\hline 21 & 8.37 & 8.43 & 8.61 & 8.66 & 8.70 & 8.74 & 8.49 & 8.57 & 8.59 & 8.63 \\
\hline \multicolumn{11}{|c|}{ Lactic acid bacterial (LAB) count } \\
\hline Fresh & 8.26 & 8.30 & 8.33 & 8.48 & 8.43 & 8.47 & 8.39 & 8.41 & 8.42 & 8.46 \\
\hline 7 & 8.48 & 8.66 & 8.65 & 8.77 & 8.71 & 8.71 & 8.70 & 8.74 & 8.72 & 8.74 \\
\hline 14 & 8.40 & 8.49 & 8.52 & 8.64 & 8.55 & 8.58 & 8.60 & 8.63 & 8.60 & 8.61 \\
\hline 21 & 8.25 & 8.30 & 8.31 & 8.48 & 8.41 & 8.44 & 8.37 & 8.31 & 8.41 & 8.43 \\
\hline \multicolumn{11}{|c|}{ Streptococcus thermophilus count } \\
\hline Fresh & 7.52 & 7.81 & 7.99 & 8.10 & 8.12 & 8.16 & 7.95 & 8.00 & 7.88 & 7.96 \\
\hline 7 & 7.93 & 8.00 & 8.20 & 8.31 & 8.26 & 8.29 & 8.20 & 8.28 & 8.16 & 8.23 \\
\hline 14 & 7.71 & 7.86 & 8.03 & 8.20 & 8.16 & 8.22 & 8.05 & 8.11 & 8.06 & 8.02 \\
\hline 21 & 7.40 & 7.75 & 7.86 & 8.02 & 7.99 & 8.11 & 7.86 & 7.89 & 7.85 & 7.92 \\
\hline \multicolumn{11}{|c|}{ Bifidobacterium sp. count } \\
\hline Fresh & - & - & 8.06 & 8.17 & - & - & 7.91 & 7.93 & - & - \\
\hline 7 & - & - & 8.24 & 8.33 & - & - & 8.13 & 8.18 & - & - \\
\hline 14 & - & - & 8.21 & 8.19 & - & - & 8.09 & 8.12 & - & - \\
\hline 21 & - & - & 8.03 & 8.13 & - & - & 7.88 & 7.90 & - & - \\
\hline \multicolumn{11}{|c|}{ Lactobacillus plantarum count } \\
\hline Fresh & - & - & - & - & 8.21 & 8.22 & - & - & 7.99 & 8.13 \\
\hline 7 & - & - & - & - & 8.29 & 8.31 & - & - & 8.24 & 8.30 \\
\hline 14 & - & - & - & - & 8.23 & 8.25 & - & - & 8.17 & 8.14 \\
\hline 21 & - & - & - & - & 8.19 & 8.20 & - & - & 8.06 & 8.12 \\
\hline
\end{tabular}

$\mathbf{C}_{1}$ : Control without oat., $\mathbf{C}_{2}$ : Control with $1 \%$ oat., $\mathbf{T}_{1}: 7.5 \%$ Red grape juice $+1.5 \%$ B. breve $+1 \%$ oat., $\mathbf{T}_{2}$ : $10 \%$ Red grape juice $+1.5 \%$ B. breve $+1 \%$ oat., $\mathbf{T}_{3}: 7.5 \%$ Red grape juice $+1.5 \%$ L. plantarum $+1 \%$ oat., $\mathbf{T}_{4}$ : $10 \%$ Red grape juice $+1.5 \%$ L. plantarum $+1 \%$ oat., $\mathbf{T}_{5}: 7.5 \%$ Apricot juice $+1.5 \%$ B. breve $+1 \%$ oat., $\mathbf{T}_{6}$ : $10 \%$ Apricot juice $+1.5 \%$ B. breve $+1 \%$ oat., $\mathbf{T}_{7}: 7.5 \%$ Apricot juice $+1.5 \%$ L. plantarum $+1 \%$ oat., $\mathbf{T}_{\mathbf{8}}: 10 \%$ Apricot juice $+1.5 \%$ L. plantarum $+1 \%$ oat.A, B, C: Means with same letter among treatments in the same storage period are not significantly different $(p 0.05<)$, a, b, $\mathbf{c}$ : Means with same letter for same treatment during storage period are not significantly different $(p 0.05<)$. 

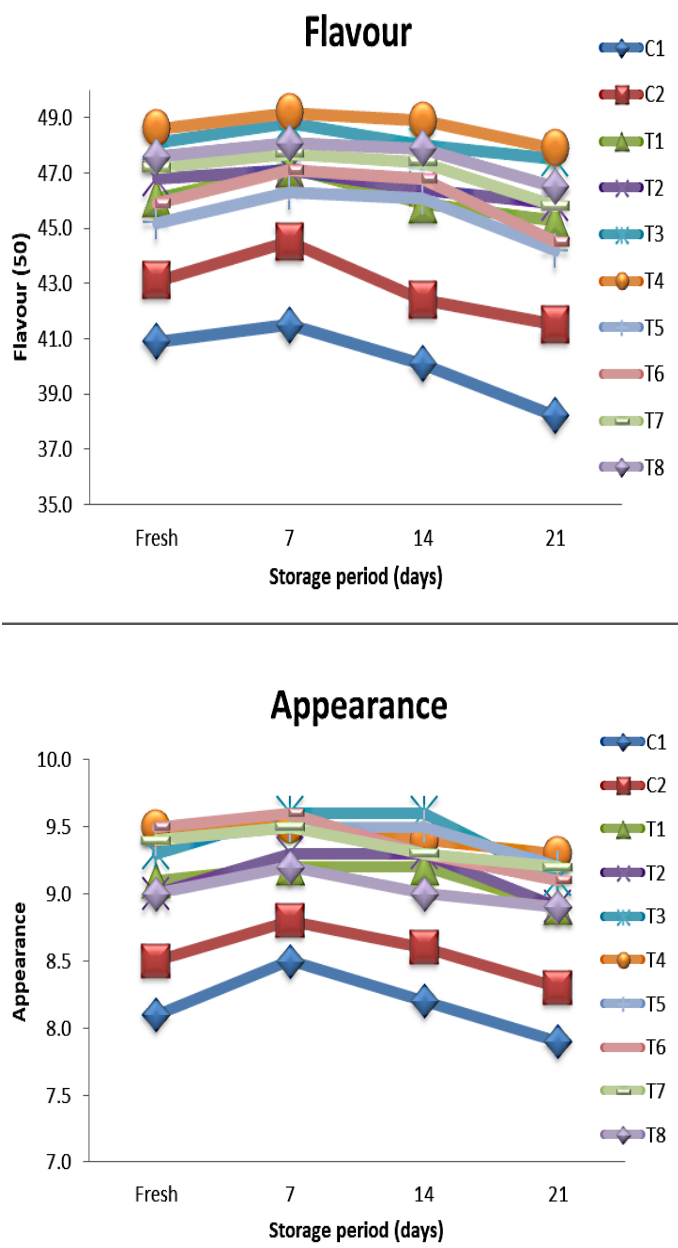
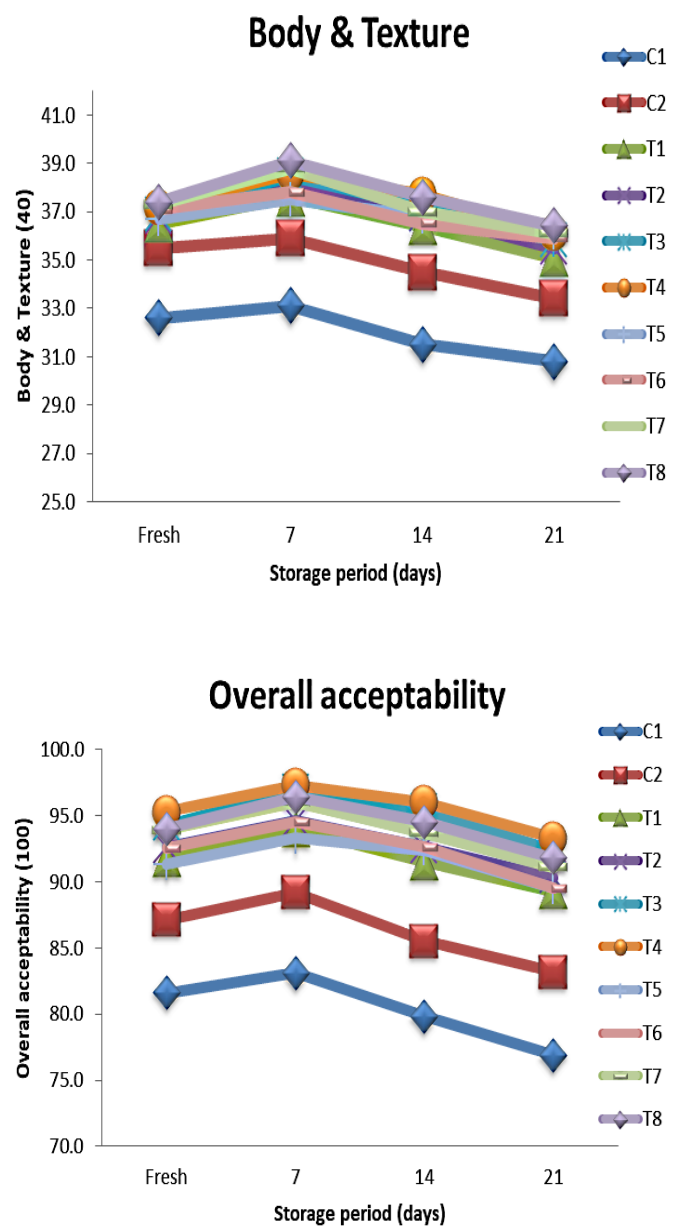

Fig. 2. Sensory evaluation of fruit-flavoured drinkable yoghurt when fresh and during storage at $\sim 5^{\circ} \mathrm{C}$ up to 21 days.

Generally, addition of fruit juices improved the body \& texture of yoghurt when fresh and all over the storage period. $\mathrm{T}_{8}$ scored the highest points compared to $\mathrm{C}_{1}$, which gained the lowest score. Results for appearance scored slightly variations when fresh and throughout the cold storage period. However, the appearance score ranged from 8.1 to 9.5 point for fresh treatments and starts to decrease all over the storage period, reaching the lowest points at 21 days, as ranging from 7.9 to 9.3 . It is clear that results of overall acceptability gained the highest points at 7 days ranging from 81.6 to 95.3 , while the progress of cold storage period led significantly to decrease in total score values to vary from 76.9 to 93.3 point at 21 days.

The fortification of drinkable yoghurt with fruit juices significantly increased the values of overall acceptability. From the previous data, it could be concluded that $\mathrm{T}_{4}$ recorded the highest overall acceptability followed by $\mathrm{T}_{3}$ and then $\mathrm{T}_{8}$, while $\mathrm{C}_{1}$ had the minimum value of overall acceptability throughout storage period. Similar results were reported by Kauseret al. (2011), Karaca et al. (2012), Abdel-Galeele et al. (2013), Güler-Akin et al. (2016), Silva et al. (2017) and Narayana \& Gupta (2018).

\section{Conclusion}

It could concluded that from such study that fruit-flavoured drinkable yoghurt can be made successfully using red grape \& apricot juices and from probiotic bacteria i.e (Bifidobacterium breve and Lactobacillus plantarum) and enriched with oat with good characteristics from chemical, physical, microbiological, rheological and sensory acceptability. The produced yoghurts can be made in a commercial way and can be sold in the market as functional products. 


\section{References}

Abdalla, M.O.M., Fawi, N.M.T., Ahmed, M.S.O., Mohamed, G.E.E. and Ahmed, G.E.M. (2015). Quality evaluation of stirred yoghurt flavoured with Guddaim (Grewiatenax) fruit. Asian J. Agric. \& Food Sci., 3, 27-33. https://pdfs.semanticscholar. org/12ac/8273233768dad62592bc22cee091ea525 4a7.pdf? ga=2.45415972.141452108.1594667259$\underline{620573037.1586886214}$

Abdel-Galeele, A.A., Sulieman, A.M., Abd El-Wahed, E.M. and Khalifa, S.A. (2013). Utilization of sebestan plum fruit nectar (Cordiadichotomaforst) in the manufacture of flavourednutraceutical yoghurt drink. Zagazig J. Agric. Res.,40,1113-1119.

Abou El Samh, M.M., Sherein, A.A. and Essam, H.H. (2013). Properties and antioxidant activity of probiotic yoghurt flavored with black carrot, pumpkin and strawberry. Int. J. Dairy Sci., 8, 48-57. http://dx.doi.org/10.3923/ijds.2013.48.57

Ahmed, E.A.M. (2017). Production of functional drinking yoghurt supplemented with strawberry and berry fruits. J. Food \& Dairy Sci., Mansoura Univ.,8, 263-266. https://jfds.journals.ekb.eg/article 38696 b5e204a91c886f3c414a73270d0c50f7.pdf

Ali, A.R.M. (2018). Incorporating of some natural and bio-materials in cheese making to improve their functional characteristics. Ph.D. Thesis, Fac. Agric., Moshtohor, Benha Univ., Egypt.

Allgeyer, L.C., Miller, M.J. and Lee, S.Y. (2010). Sensory and microbiological quality of yoghurt drinks with prebiotics and probiotics. J. Dairy Sci., 93,44714479. https://doi.org/10.3168/jds.2009-2582

AOAC, (2012). Official methods of analysis. Association of Official Analytical Chemists $19^{\text {th }}$ ed., Published by AOAC International, Gaithersburg, Maryland, USA.

American Public Health Association (APHA, 2004). Standards methods for the examination of dairy products. $17^{\text {th }}$ ed., H. Michael Wehr and Joseph F. Frank, editors. American Public Health Association, Washington, DC, USA. https://aiph.aphapublications.org/doi/ abs/10.2105/9780875530024

BSI, (1985). Determination of pH value. BS770 Part 5. British Standards Institution, London, U.K.

BSI, (1993). Determination of Enterobacteriaceae in microbiological examination of food and animal feeding stuffs. BSI 5763, British Standards Institution, London, U.K.
BSI, (2010). Milk: determination of titratable acidity (Reference method) ISO, 6091, British Standards Institution, London, U.K.

Bujalance, C., Jiménez-Valera, M., Moreno, E., RuizBravo, A. (2006). A selective differential medium for Lactobacillus plantarum. J. Micro. Methods, 66, $572-$ 575.https://doi.org/10.1016/j.mimet.2006.02.005

Buriti, F.C.A., Cardarelli, H.R. and Saad, S.M.I. (2007). Biopreservation byLactobacillusparacasei in co-culture with Streptococcus thermophilus in potentially probiotic. J. Food Protect.,70, 228-235. https://doi.org/10.4315/0362-028X-70.1.228

Cardarelli, H.R., Saad, S.M.I., Gibson, G.R. and Vulevic, J. (2007). Functional petit-suisse cheese: Measure of the prebiotic effect.Anaerobe, 13, 200-207. https:// doi.org/10.1016/j.anaerobe.2007.05.003

Dave, R.I. and Shah, N.P. (1996). Evaluation of media for selective enumeration of Streptococcus thermophilus, Lactobacillus delbrueckiissp. bulgaricus, Lactobacillus acidophilus and Bifidobacteria.J. Dairy Sci.,79, 1529-1536.https:// doi.org/10.3168/jds.s0022-0302(96)76513-x

Desouky, M.M. (2018). Effect of using cactus pear pulp on the properties of goats' milk bioyoghurt drinks. Egypt. J. Food Sci.,46, 25-41. https://ejfs.journals.ekb.eg/article_30434 ba1da89114af246db3074838299377bf.pdf

de Souza, C.H.B., Buriti, F.C.A., Behrens, J.H. and Saad, S.M.I. (2008). Sensory evaluation of probiotic Minas fresh cheese with Lactobacillus acidophilus added solely or in co-culture with a thermophilic starter culture. Int. J. Food Sci. \& Tech., 43, 871-877. https://doi.org/10.1111/j.1365-2621.2007.01534.x

Dey, K.C., Begum, R., Rahman, M.R.T., Sultana, A., Akter, S. and Janny, R.J. (2014). Development of fruit juice yoghurt by utilization of jackfruit juice: A preliminary study on sensory evaluation, chemical composition, and microbial analysis. Int. J. Eng. Res. \& Tech.,3, 1074-1079. https://www.researchgate.net/ publication/269629756

Do Espirito Santo, A.P., Silva, R.C., Soares, F.A.S.M., Anjos, D., Gioielli, L.A. and Oliveira, M.N. (2010). Açai pulp addition improves fatty acid profile and probiotic viability in yoghurt. Int. Dairy J., 20, 415422. https://doi.org/10.1016/j.idairyj.2010.01.002

El-Alfy, M.B., El-Nagar, G.F., Abd El-Aty, A.M., Essawy, E.A. and Hammad, M.N.A. (2018). Making of fortified yoghurt with colostrum. Egypt. J. Appl. Sci., 33, 61-75.

Egypt. J. Food Sci. 48, No.1 (2020) 
Elliker, P.R., Anderson, A.W. and Hannesson, G. (1956). An agar culture medium for lactic acid streptococci and lactobacilli. J. Dairy Sci.,39, 1611-1612._https:// www.journalofdairyscience.org/article/S00220302(56)94896-2/pdf

Farahat, A.M. and El-Batawy, O.I. (2013). Proteolytic activity and some properties of stirred fruit yoghurt made using some fruits containing proteolytic enzymes. World J. Dairy \& Food Sci., 8, 38-44. http://www.idosi.org/wjdfs/wjdfs8(1)13/5.pdf

Güler-Akin, M.B., Ferliarslan, I. and Akin, M.S. (2016). Apricot probiotic drinkable yoghurt supplied with inulin and oat fiber. Adv. Microbiol., 6, 999-1009. http://dx.doi.org/10.4236/aim.2016.614094

Gunawardhana, W.A.D.C and Dilrukshi, H.N.N. (2016). Development of yoghurt drink enriched with avocado pulp (Perseaamericana). Int. J. Adv. Scient. Res. \&Manag., 1, 97-102. http://ijasrm.com/wp-content/ uploads/2016/09/IJASRM_V1S9_122_97_102.pdf

Hamad, M.N.F., Ismail, M.M. and Elraghy, E.M. (2017). Effect of fortification with guava pulp on some properties of bio-Rayeb milk made from goat's milk. Acta Sci. Nutri. Health, 1, 9-20. https://www. actascientific.com/ASNH/pdf/ASNH-01-0015.pdf

Hammad, M.N.A. (2019). Studies on producing some therapeutic dairy products. Ph.D. Thesis, Fac. Agric., Moshtohor, Benha Univ., Egypt.

Hassanein, A.M., Yousef, E.T.A. and El-Shazly, H.A.M. (2014). Effect of concentrated pomegranate on probiotic yoghurt. World Appl. Sci. J., 30, 567-574. https://www.idosi.org/wasj/wasj30(5)14/5.pdf

Hossain, M.N., Fakruddin, M. and Islam, M.N. (2012). Quality comparison and acceptability of yoghurt with different fruit juices. J. Food Process. \& Tech., 3, 171-175. https://doi.org/10.4172/21577110.1000171

Ismail, E. A. (2007). Characterization and genetic improvement of lactobacilli for application in probiotic dairy products. Ph.D. Thesis, Fac. Agric. \&Nutr. Sci., Christian Albrecht's Univ., Kiel, Germany. https://nbn-resolving.org/ urn:nbn:de:gbv:8-diss-26154

Ismail, M.M. (2015). Improvement of nutritional and healthy values of yoghurt by fortification with rutub date. J. Microbiol., Biotech. \& Food Sci.,4, 398-406. https://doi.org/10.15414/JMBFS.2015.4.5.398-406

Ismail, M.M., Hamad, M.F. and Elraghy, E.M. (2016). Rheological, physicochemical, microbial, and sensory properties of bio-rayeb milk fortified with

Egypt. J. Food Sci. 48, No.1 (2020) pulp. Int. J. Food Sci. \& Biotech., 1, 8-18. http:// article.sciencepublishinggroup.com/html/10.11648.j .ijfsb.20160101.12.html

Karaca, O.B., Saydam, I.B. and Güven, M. (2012). Physico-chemical, mineral, and sensory properties of set-type yoghurts produced by addition of grape, mulberry and carob molasses (Pekmez) at different ratios. Int. J. Dairy Tech.,65, 111-117. https://doi. org/10.1111/j.1471-0307.2011.00731.x

Kauser, S., Saeed, A., Kalim, I., Salariya, A.M. and Iqbal, M. (2011). Studies on the development and nutritional evaluation of apricot based yoghurt. Pak. J. Biochem. Mol. Biol.,44, 156-159. http:// pjbmb.org.pk/images/PJBMBArchive/2011/ PJBMB 44 4 Dec 2011/08.pdf

Kavas, N. and Kavas. G. (2016). Functional probiotic yoghurt production with pomegranate (PunicagranatumL.) juice concentrate fortification. J. Scient. Res. \& Rep.,10, 1-10. https://doi. org/10.9734/JSRR/2016/23937

Keogh, M.K. and O'Kennedy, B.T. (1998). Rheology of stirred yoghurts as affected by added milk fat, protein, and hydrocolloids. J. Food Sci.,63, 108-112. https://doi.org/10.1111/j.1365-2621.1998.tb15687.x

Kermiche, F., Boulekbache-Makhlouf, L., Felix, M., Harkat-Madouri, L., Remini, H., Madani, K. and Romero, A. (2018). Effects of the incorporation of cantaloupe pulp in yoghurt: Physico-chemical, phyto-chemical, and rheological properties. Food Sci. Tech. Int., 24, 585-597. https://doi. org/10.1177/1082013218776701

Kosikowski, F.V. (1984). Cheese and fermented milk foods. $2^{\text {nd }}$ ed., printing Brooktonalds, New York 14817, USA.

Kumar, A. and Kumar, D. (2016). Development of antioxidant rich fruit supplemented probiotic yoghurts using free and micro-encapsulated Lactobacillus rhamnosus culture. J. Food Sci. Tech., 53, 667-675. https://doi.org/10.1007/s13197-0151997-7

Lees, G.J. andJago, G.R. (1969). Methods for the estimation of acetaldehyde in cultured dairy products. Aust. J. Dairy Tech., 24,181-185.

Lees, G.J. and Jago, G.R. (1970). The estimation of diacetyl in the presence of other carbonyl compounds. J. Dairy Res.,37, 129-132. https://doi. org/10.1017/S0022029900013145 
Mangia, N.P., Murgia, M.A., Fancello, F., Nudda, A. and Deiana, P. (2014). Influence of myrtle Juice and syrup on microbiological, physico-chemical and sensory features of goat's milk yoghurt made with indigenous starter culture. J. Microb. Biochem. Tech.,6, 370-374. https://doi.org/10.4172/19485948.1000171

Mansouri, A., Embarek, G., Kokkalou, E. and Kefalas, P. (2005). Phenolic profile and antioxidant activity of the Algerian ripe date palm fruit (Phoenixdactylifera). Food Chem., 89, 411-420. https://doi.org/10.1016/j.foodchem.2004.02.051

Marchiani, R., Bertolino, M., Belviso, S., Giordano, M., Ghirardellom, D., Torri, L., Piochi, M. and Zeppa, G. (2016). Yoghurt enrichment with grape pomace effect of grape cultivar on physico-chemical, microbiological,and sensory properties. J. Food Quality, 39, 77-89. https://doi.org/10.1111/jfq.12181

Marshall, R.T. (2005). Standard methods for the examinationofdairy products. Amer. Public Health Assoc., Washington, DC.

Matter, A.A., Mahmoud, E.A.M. and Zidan, N.S. (2016). Fruit flavored yoghurt: chemical, functional and rheological properties. Int. J. Enviro. \&Agric. Res., 2, 57-66. https://ijoear.com/Paper-May-2016/ IJOEAR-MAY-2016-7.pdf

Mbaeyi-Nwaoha, I.E., Umeh, L.C., Igbokwe, C.J., Obodoechi, C.M. and Okoronkwo, N.C. (2017). Production and quality evaluation of flavoured yoghurt from graded levels of sweet variety of African bush mango "Ugiri" (Irvingiagabonensis) juice and pulp. Food Sci. \& Tech., 5, 56-69. http:// www.hrpub.org/download/20170228/FST311008667.pdf

Meenakshi, V.R., Ganya, S. and Umamaheswari, T.S. (2018). Formulation of value enriched probiotic fruit yoghurt. Int. J. Curr. Microbiol. \& App. Sci., 7, 14401450. https://doi.org/10.20546/ijcmas.2018.703.172

Narayana, N.M.N.K. and Gupta V.K. (2018). Storage changes and shelf life of strawberry set yoghurt made by milk standardized using ultrafiltered skim milk retentate. Int. J. Sci. \& Tech. Res., 7, 261-268. http://www.ijstr.org/paper-references. php?ref=IJSTR-0818-19438

Petersen, B.L., Dave, R.I., McMahon, D.J., Oberg, C.J. and Broadbent, J.R. (2000). Influence of capsular and ropy exopolysaccharide-producing Streptococcus thermophilus on Mozzarella cheese and cheese whey. J. Dairy Sci., 83, 1952-1956. https://doi. org/10.3168/jds.S0022-0302(00)75071-5
Raut, V., Sawant, P., Sawant, D. and Ingole, A.S. (2015). Studies on preparation of mango yoghurt drink. Asian J. Dairy \& Food Res.,34, 13-17. https:// arccjournals.com/journal/asian-journal-of-dairyand-food-research/DR-929

Roy, D.K.D., Saha, T., Akter, M., Hosain, M., Khatun, H. and Roy, M.C. (2015). Quality evaluation of yoghurt supplemented with fruit pulp (Banana, Papaya and Watermelon). Int. J. Nutr. \&Food Sci., 4, 695-699. http://article.sciencepublishinggroup. com/html/10.11648.j.ijnfs.20150406.25.html

Salih, M.A.M. and Abdalla, M.O.M. (2017). Physicochemical and sensory characteristics of stirred yoghurt flavoured with mango (MangiferaindicaL.) during storage period. Pak. J. Nutr., 16, 378-383. http://dx.doi.org/10.3923/pjn.2017.378.383

Saranyambiga, D., Narayanan, R. and Vadivoo, V.S. (2017). Development of Jamunsynbiotic smoothie. Int. J. Sci. Env. \& Tech., 6, 2179-2189. https:// krishikosh.egranth.ac.in/handle/1/5810030165

SAS, (2008). Statistical Analysis System. SAS User>s Guide Statistics/ STAT Ver. 9.2 SAS Inst., Inc., Cary, NC, USA.

Sengupta, S., Chakraborty, A. and Bhowal, J. (2014). Production and evaluation of yoghurt with watermelon (Citrulluslanatus) juice. J. Int. Acad. Res. Multidisciplinary, 2, 249-257.

Silva, F.A., De Oliveira, M.E.G., de Figueiredo, R.M.F., Sampaio, K.P., de Souza, E.L., de Oliveira, C.E.V., Pintado, M.M.E. and Queiroga, R.R.E. (2017). The effect of Isabel grape addition on the physico-chemical, microbiological and sensory characteristics of probiotic goat milk yoghurt. Food \&Funct., 82121-2132. https://doi.org/10.1039/ c6fo01795a

St-Onge, M.P, Farnworth, E.R, Jones, P.J. (2000) Consumption of fermented and nonfermented dairy products: effects on cholesterol concentrations and metabolism. Am J Clin Nutr.,71, 674-681. https://doi. org/10.1093/ajcn/71.3.674

Subhashini, S., Baskaran, D., Dhanalakshmi, B., Murugan, B. and Manoharan, A.P. (2018). Physicochemical properties of grape (VitisviniferaL.) pomace fortified drinkable yoghurt. Int. J. Curr. Microbiol. App. Sci., 7, 2875-2880. https://www.ijcmas.com/75 2018/S.\%20Subhashini,\%20et\%20al.pdf

Tamime, A.Y. and Robinson, R.K. (1999). Yoghurt: Science and Technology ( $2^{\text {nd }}$ ed. $)$, Cambridge, UK: Wood head publishing Ltd.

Egypt. J. Food Sci. 48, No.1 (2020) 
Tiwari, P.K., Asgar, S., Uprit, S., Chauhan, M., Sandey, K.K. and Shinde, N.W. (2019). Effect of oat flour addition on the viability of drink. Int. J. Livestock Res.,9, 66-73. https://dx.doi.org/10.5455/ ijlr.20180430020654

\author{
مزارع جديدة مساعدة من البكتريا الداعمة للحيوية لانتاج مشروب الزبادى المطعم بالفاكهة \\ السيد السيد علي اسماعيل ا ، محمد عيد شنانةا ، محمد بديرالألفي ا، ايهاب عبد الباقي عيسوي ب و سناء

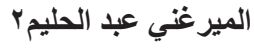 \\ ا قسم الألبان - كلية الزراعة بمشتهر - جامعة بنها مصر \\ r قسم بحوث تكنولوجيا تصنيع الألبان ـ معهز بحوث تكنولوجيا الأغذية ـ مركز البحوث الزراعية ـ مصر
}

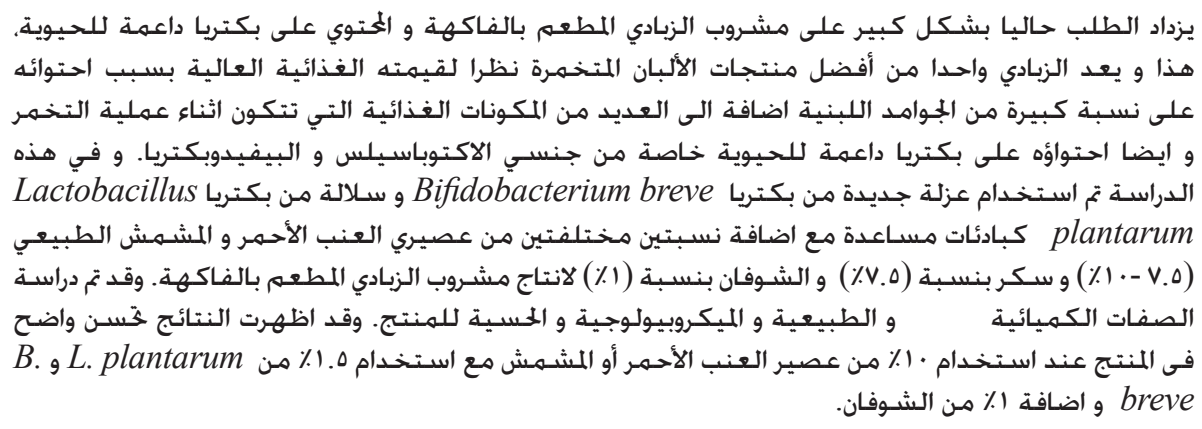

Egypt. J. Food Sci. 48, No.1 (2020) 